\title{
POLICIES UNDERLYING THE ADJUSTMENT OF CREDITORS' SECURITY RIGHTS IN FLXTURES
}

Conflicts over security rights in growing crops, railroad rolling stock, or consumer or industrial fixtures ${ }^{x}$ of a debtor may arise between prior, long-term real estate mortgagees, whose claims are based upon local fixture law or afteracquired property clauses, and subsequent chattel mortgagees or conditional vendees. ${ }^{2}$ If this conflict is resolved in favor of the chattel mortgagee by granting this "new money" creditor the right to remove the particular asset, the possibility of damage to the security of the "old money" raises further problems.

Policy considerations indicate that the "new money" interest should be favored. The need to provide for expansion of business enterprise and the modernization of plants seems more important to the economy than granting maximum protection for quantitatively larger long-term obligations. ${ }^{3}$ Furthermore, favoring the "new money" should make short-term credit relatively more available. This, in turn, may make it possible for the debtor to forestall impending bankruptcy. 4 For instance, a new fixture in a plant might bring increased earnings, and in time re-establish the business on a profitable basis.

This decision that "new money" should be favored, whether or not secured by the crop, fixture, or rolling stock which it financed, will be taken into account by subsequent long-term lenders. ${ }^{5}$ Inequity to the prior creditors would only result, therefore, if removal of the particular security caused either physical damage to the freehold or destroyed the going concern value of a business,

I It will be assumed in this comment that local law has already designated the particular chattel a fixture.

3 The source of this aspect of the problem is in part the possibility that a prior long-term interest may not be limited to the security existing at the time of the loan, but may include future property acquired by the debtor. Again, the distinction between secured and unsecured creditors makes the problem of importance to both parties. The debt is usually paid off faster than the particular security depreciates, making the right of removal and sale coupled with a deficiency judgment more likely to return a greater percentage of the debt than unsecured general creditor status.

3 Gilmore, Chattel Security: II, 57 Yale L. J. 761, 782 (r948); see Kratovil, Fixtures and the Real Estate Mortgagee, $97 \mathrm{U}$. of $\mathrm{Pa}$. L. Rev. 180,200 (r948), for a discussion of the need to protect "new money" interests. In general, the need in a small business just getting started for new equipment, or of wage earners who may not be able to purchase except on credit, or of the farmer unable to buy machinery without giving a crop mortgage, indicates the need for protection of the "new money," which may bring with it low interest rates. See Institutional Doctrine of Fixtures: Material Injury to the Freehold within the Meaning of the Uniform Conditional Sales Act, 22 Corn. L. Q. 42I, 426 (I937).

4 During the depression the federal government financed farmers who were unable to get sufficient funds to buy seed for the next year's crop because of pending insolvency. For a discussion of the agricultural financing problems facing the government at that time, see Mortgages on Future Crops as Security for Government Loans, 47 Yale L. J. 98 (1937).

$s$ Of course, unless provision is made, inequity will arise in the case of persons relying on the previous rules. Thus, there would be some inequity in those states which now favor the "old money" interest. 
or both. ${ }^{6}$ Thus, the success of a particular legal solution to the general problem may be judged by the manner in which it compromises between the policy favoring the "new money" with that of protecting the underlying security of the prior creditors. An examination of existing and proposed rules in the crop, fixture, and rolling stock cases will provide a basis for such a judgment.

Traditionally it is in the financing of rolling stock that "new money" has received the greatest protection. ${ }^{7}$ The equipment trust was devised principally for the purpose of defeating the interest of the prior long-term mortgagee fortified with an after-acquired property clause. ${ }^{8}$ This was possible through the title-retention device of the trust, and the lease of the rolling stock to the railroads by the trustee. ${ }^{9}$ However, the equipment bond holders of the trust have exercised their legal right of removal and sale of the rolling stock only twice in the last fifty years. ${ }^{\mathrm{xO}}$ In one of these cases the road was actually dismantled ${ }^{\mathrm{xr}}$ and in the other the operating scale was substantially decreased. ${ }^{.2}$ The removal caused little damage to the security of the "old money" since an intended contraction of the business at least partially warranted the removal. In the great majority of the cases the continued undiminished operation of the railroad is contemplated. The disruption of operation and damage to the security of the "old money" that would attend a physical removal of the rolling stock leads either to the payment of the "new money" or to the award of a preference in reorganization. ${ }^{13}$ And perhaps more important, the power struggle attendant

${ }^{6}$ Since crops must be cut and sold in any case, little or no question of impairing the "old money" security is raised. At the opposite pole is the industrial fixture case, involving both the possibility of destroying going concern value and damaging the physical freehold on removal of the fixture by the "new money." In between these polar examples are the consumer fixtures, which would only involve the physical damaging of the freehold, and the rolling stock situation, where removal would only destroy going concern value belonging to the prior mortgagee.

7 One reason the law was made clear at an early period in railroad financing was the demand for railroads in the westward advance after the Civil War. Thus, the Baldwin Locomotive works and other dealers in railroad equipment found friendly legislatures. As a result, many states legitimized the "car trust" long before those states had recognized the conditional sales contract. Bogert, The Proposed Uniform Conditional Sales Act, 3 Corn. L. Q. I, 9 (I9I7); Burdick, Codifying the Law of Conditional Sales, $18 \mathrm{Col}$. L. Rev. ro3 (r9x8). One effect of this complete protection of equipment bond holders is the low interest rates on equipment obligations. For a comparison of equipment obligations to long term railroad mortgages see Dewing, Corporation Securities 338-4I (I934).

${ }^{8}$ Since rolling stock was generally not considered a fixture, the long-term mortgagees of the railroad used the after-acquired property clause to acquire an interest in future rolling stock purchased by the railroad.

9 Other devices used by the railroad were conditional sales and mortgage bonds plans. See Dewing, Corporation Securities 343-49 (I934).

xo Dewing, Corporation Securities 373-74 (I934).

Ix The Buffalo \& Susquehanna Railway was dismantled in I9I6.

${ }^{12}$ In 1908 the Detroit, Toledo, \& Ironton Railway was decreased in size.

I3 Besides dismantling or reorganizing the railroad, the "old money" creditors may sell the defunct railroad. Like the reorganizing creditors, the purchaser will desire to retain the rolling stock. As a result either the purchaser will assume the "new money" debt or the "old money" will pay off the obligation with a resulting increase in purchase price. 
upon a reorganization may lead the prior creditors to pay off the "new money" interests to get them out of the way.

An equivalent degree of protection for the "new money" interest has not been realized in the crop and fixture cases. In the former, the difficulty arises from the rule that growing crops are part of the land. Thus where no crop mortgagee is involved, the real estate mortgagee traditionally has recourse to the crop before the general creditors. Where a crop mortgagee is present the problem involves determining whether the real estate interest's security is to be decreased or whether the crop mortgagee is to be given only general creditor status. Some courts, recognizing the need of protecting the crop mortgagee, created the fiction that the crop was constructively severed from the freehold upon being subjected to a chattel mortgage. ${ }^{I_{4}}$ Other courts reached a similar result by reasoning that the prior mortgagee's security includes only the land and not the crops. ${ }^{.5}$ This rationale conflicts with that applied in cases where the "old money" mortgagee competes for the crop only with general creditors. Consistency gives way to the need for protecting the "new money" interest. A few states, however, remain consistent and include the crop in the prior mortgagee's security, thus defeating the "new money" interest. ${ }^{16}$ The simplest and perhaps most equitable solution to this problem would be to prohibit recourse to the crop by the foreclosing mortgagee of the land both where a crop mortgage is involved and where only general creditors assert an interest. Furthermore, such a result would involve no danger of damage to the prior creditor's remaining security. ${ }^{27}$

The consumer and industrial fixture ${ }^{\mathrm{I}}$ cases raise more difficult problems. Removal may result in damage to the security of the "old money,"rg a possibility that did not arise in the crop cases. "All or nothing" rules have been developed to resolve the controversy. The courts grant the "new money" lienor the position of secured creditor only when removal would not "materially impair" the prior mortgagee's security. ${ }^{20}$ Two tests have been used by the courts

${ }^{4}$ Tolland Co. v. First State Bank of Keenesburg, 95 Colo. 32I, 35 P. 2d 867 (I934); Red River National Bank v. Summers, 30 S.W. 2 d 726 (Tex. Civ. App., I930). For a rejection of the constructive severance theory see Wooton v. White, $90 \mathrm{Md}$. 64, 44 Atl. 1026 (I899).

Is Coffey v. Land, I76 Miss. Ir4, I67 So. 49 (I936); Southern Trust Co. v. First City Bank \& Trust Co. of Hopkensville, 259 Ky. I51, 82 S.W. 2d 205 (1935); Equitable Life Insurance Co. v. Read, 21 5 Iowa 700, 246 N.W. 779 (I933); 2 Glenn, Mortgages § 202.I (1943).

${ }^{16} \mathrm{John}$ Hancock Mutual Life Insurance Co. v. Watson, 200 IIl. App. 3 I 5 (I9I6); Thompson v. Union Warehouse Co., iro Ala. 499, I8 So. ros (1895); Mortgages on Future Crops as Security for Government Loans, 47. Yale I. J. 98, 104 (1937).

17 Note 6 supra.

${ }^{8}$ Industrial fixture includes commercial cases, i.e. retail stores.

19 Note 6 supra.

${ }^{20} \mathrm{~A}$ minority of states, for instance Massachusetts, do not apply this test. Instead they completely defeat the "new money" interest in all situations. For a discussion and cases concerning the majority and minority rules see Kratovil, op. cit. supra note 7, at r99-202. 
to determine the meaning of "materially impair": (I) physical injury to the freehold by the removal, ${ }^{21}$ and (2) destruction of the going concern. ${ }^{22}$ The latter test applies principally to industrial fixture cases and results, in almost every case, in defeating the "new money" interest."2 The application of the former rule in either the consumer or industrial fixture cases usually results in victory for the "new money," ${ }^{2}$ and may permit actual damage to the remaining security of the prior creditors. This result follows from the judicial definition of "material injury"- the physical harm actually inflicted in most cases is held insufficient to prevent removal. The application of either rule may be inequitable in those cases in which it is difficult to determine in advance whether removal will result in damage to the going concern or in material injury to the freehold. Thus, neither of these "all or nothing" rules properly balances the relevant policy considerations.

The authors of the proposed Uniform Commercial Code ${ }^{25}$ attempt to balance the conflicting interests in a more certain and equitable way. ${ }^{26}$ Their approach in the fixture cases gives a choice of removal and sale to the "new money" interest. ${ }^{27}$ Where the removal of a fixture causes physical damage to the freehold

${ }^{2 x}$ Campbell v. Roddy, 44 N.J. Eq. 244, I4 Atl. 279 (I888); Swift Lumber \& Fuel Co. v. Elwanger, I27 Neb. 740, $25^{6}$ N.W. 875 (1934).

22 This view is generally characterized as the "institutional" approach. Here the right of removal is denied to the credit vendor of a fixture when the removal would result in materialimpairment of the efficient functioning of the mortgaged property viewed as an operating institution. This approach is presently adopted in New Jersey, California, and Kentucky. The discussion in Rights of a Conditional Vendor in Chattels Affixed to Realty as against an Unassenting Prior Mortgagee, $8_{3} \mathrm{U}$. of Pa. L. Rev. 916 (1935), favors this view, while in Institution Doctrine of Fixtures: Material Injury to the Freehold within the Meaning of Uniform Conditional Sales Act, 22 Corn. L. Q. 42 (I937), the position is attacked.

${ }^{23}$ Smyth Sales Corp. v. Norfolk Building \& Loan Ass'n, Ir6 N.J. 293, I84 Atl. 204 (I936); Dauch v. Ginsburg, 2I4 Cal. 540, 6 P. 2d 952 (r93I); Morrow Manufacturing Co. v. Race Creek Coal Co., 222 Ky. 807, 2 S.W. 2 d 662 (r928).

${ }^{24}$ In Kleps, Uniformity versus Uniform Legislation: Conditional Sale of Fixtures, 24 Corn. L. Q. 394, 404 (r939), the statement is made in a footnote that no removal has caused material impairment of the prior mortgagee's security in New York from I930 to I939.

${ }^{25}$ American Law Institute \& National Conference of Commissioners on Uniform State Laws, Uniform Commercial Code, Proposed Final Draft (1950).

${ }^{26}$ The Commercial Code does not change existing rules in financing rolling stock. Uniform Commercial Code $\$ 9-312$ (I950). However, "[i]n case the collateral is growing crops the interest of a lender who makes an advance, incurs a new obligation or releases a perfected security interest during the production season or not more than three months before the crops are planted or otherwise become growing crops, in order to enable the debtor to produce them, takes priority over the interest of an earlier secured lender to the extent that the earlier lender's interest secures obligations (such as rent, interest or mortgage principal amortization) due more than six months before the crops are planted or otherwise become growing crops even though the earlier lender's interest was perfected prior to the interest of the later enabling lender." Tbid., at § 9-312(4). Clearly this suggested change protects the crop mortgagee.

27 Section 7 of the Uniform Conditional Sales Act adopted the normal "material impairment" test for fixture cases, but did not specifically direct the section to the prior mortgageesubsequent creditor situation. However, some courts applied it in that type of case. The difficulty with the solution adopted in Section 7 is that the choice of removal is left up to an in- 
they assess the "new money" interest with the cost of repairs. ${ }^{28}$ This limitation on the right of removal prevents impairment of the prior mortgagee's security except in the industrial fixture cases where "going concern" value is destroyed.

The question of whether this type of damage is so significant as to militate against the adoption of the Code solution may be answerable on the basis of the analysis suggested in the discussion of the railroad rolling stock cases. Given a going concern value substantially greater than the dismantled value of the particular assets, the adoption of a legal rule favoring the subsequent creditors-whether or not that rule requires payment of damages caused by removal -provides inducement for a settlement of the "new money" claims without resort to actual removal. In such cases the prior creditors' desire to protect the going concern value of the enterprise should lead them either to pay the "new money" claims outright or accord them some preference in reorganization.39 And, as in the railroad cases, the "new money" claims may be relatively so small that they will be paid off merely to keep the fruits of reorganization for the prior creditors.

Other factors have some bearing on those cases in which a high going concern value favors reorganization instead of dismantling. The dismantled value of the particular fixture and its importance to the operation of the business, the ratio of the amount of prior real estate mortgage debt to subsequent fixture indebtedness, and factors affecting bargaining positions of the two interests will influence the ultimate resolution of the confiict. None the less, in those cases where substantial damage to going concern value would result from removal of the fixtures, the "new money" interest usually receives the value of its security without actual resort to removal..$^{30}$

While the proposed Uniform Commercial Code achieves the goal of fair and certain rules and protection of the "new money" in the fixture, crop, , $^{3 \mathrm{x}}$ and rolling stock ${ }^{32}$ cases more satisfactorily than the case-to-case application of traditional legal rules, final solution of the problem should reflect considerations of economic policy. The economic desirability of debt financing and the relative merits of long- and short-term private debt should be carefully examined. All

definite standard set by the court. This the Commercial Code corrects by permitting the "new money" lienor to remove on default provided he fulfills all requirements. Uniform Commercial Code \& 9-313 (I950); Kripke, The "Secured Transactions" Provisions of the Uniform Commercial Code, 35 Va. L. Rev. 577, 6rI-12 (1949).

${ }^{28}$ One result of this limitation is that when the cost of repairs on removal approximates the resale value of the fixture, then the "new money" lender is without a realistic remedy to gain his secured position.

29 As to other possibilities of payment, see note $\mathrm{I}_{3}$ supra.

${ }^{30}$ Some inequity may arise in the few industrial fixture cases where actual removal does take place causing destruction of the going concern value. In such cases it has been suggested by Professor Gilmore that some kind of preference replace the normal remedy of self-help. Gilmore, op. cit. supra note 3 , at 783 .

${ }^{31}$ Note 26 supra. ${ }^{32}$ Ibid. 
portions of the Code bearing on the debt problem should be judged not only by the criteria of equity and certainty but also by their effects on the entire economy. Thus, a single enterprise with a heavy fixed debt may, in a temporary economic decline, be forced into insolvency, with all of the consequent expense of reorganization and disturbance of operations and business relations. Again, in terms of the entire economy a relatively heavy volume of fixed debt may well mean the difference between "a mild recession and a precipitous, catastrophic deflation." ${ }_{33}$ Short-term debt financing is said to be worse in its effect on both the single enterprise and the entire economy. "All debt involves short-term fixed claims for interest payments; and all long-term obligations become shortterm obligations sometime." 35 To the extent that the framers of the Code have not considered these issues, their work should be regarded as incomplete.

${ }^{33}$ Simons, Federal Tax Reform, 14 Univ. Chi. L. Rev. 20, 65 (I946).

34 Simons, Economic Policy for a Free Society I6 6 -66 (I948).

${ }^{35}$ Simons, Federal Tax Reform, I4 Univ. Chi. I. Rev. 20, 65 (1946). 